\title{
PERFORMANCE OF AN ANAEROBIC-AEROBIC REACTOR AND KINETIC STUDY OF ORGANIC MATTER REMOVAL OF CATTLE SLAUGHTERHOUSE EFFLUENT
}

\author{
CRISTIANE KREUTZ ${ }^{1}$, FERNANDO H. PASSIG ${ }^{2}$, KARINA Q. DE CARVALHO ${ }^{3}$, \\ JULIANA B. R. MEES ${ }^{4}$, SIMONE D. GOMES ${ }^{5}$
}

\begin{abstract}
This paper sought to evaluate the behavior of an upflow Anaerobic-Aerobic Fixed Bed Reactor (AAFBR) in the treatment of cattle slaughterhouse effluent and determine apparent kinetic constants of the organic matter removal. The AAFBR was operated with no recirculation (Phase I) and with $50 \%$ of effluent recirculation (Phase II), with $\theta$ of $11 \mathrm{~h}$ and $8 \mathrm{~h}$. In terms of $\mathrm{pH}$, bicarbonate alkalinity and volatile acids, the results indicated the reactor ability to maintain favorable conditions for the biological processes involved in the organic matter removal in both operational phases. The average removal efficiencies of organic matter along the reactor height, expressed in terms of raw COD, were $49 \%$ and $68 \%$ in Phase I and $54 \%$ and $86 \%$ in Phase II for $\theta$ of $11 \mathrm{~h}$ and $8 \mathrm{~h}$, respectively. The results of the filtered COD indicated removal efficiency of $52 \%$ and $\mathrm{k}=0.0857 \mathrm{~h}^{-1}$ to $\theta$ of $11 \mathrm{~h}$ and $42 \%$ and $\mathrm{k}=0.0880 \mathrm{~h}^{-1}$ to $\theta$ of $8 \mathrm{~h}$ in the Phase I. In Phase II, the removal efficiencies were $59 \%$ and $51 \%$ to $\theta$ of $11 \mathrm{~h}$ and $8 \mathrm{~h}$, with $\mathrm{k}=0.1238 \mathrm{~h}^{-1}$ and $\mathrm{k}=0.1075 \mathrm{~h}^{-1}$, respectively. The first order kinetic model showed good adjustment and described adequately the kinetics of organic matter removal for $\theta$ of $11 \mathrm{~h}$, with $\mathrm{r}^{2}$ equal to 0.9734 and 0.9591 to the Phases I and II, respectively.
\end{abstract}

KEYWORDS: kinetic, cattle slaughterhouse, combined treatment system.

\section{DESEMPENHO DE UM REATOR ANAERÓBIO-AERÓBIO E ESTUDO CINÉTICO DE REMOÇÃO DE MATÉRIA ORGÂNICA DE EFLUENTE BOVINO}

RESUMO: O objetivo deste estudo foi avaliar o desempenho de um Reator Anaeróbio-Aeróbio de Leito Fixo (RAALF) com escoamento ascendente, no tratamento de efluente bruto de matadouro bovino, e obter constantes cinéticas aparentes da remoção de matéria orgânica. O RAALF foi operado sem recirculação (Etapa I) e com 50\% de recirculação do efluente (Etapa II), com $\theta$ de 11 h e $8 \mathrm{~h}$. Em termos de $\mathrm{pH}$, alcalinidade a bicarbonato e ácidos voláteis, os resultados indicaram que o RAALF apresentou capacidade em manter condições favoráveis para os processos biológicos envolvidos na remoção de matéria orgânica, em ambas as etapas operacionais. As eficiências médias de remoção de matéria orgânica ao longo da altura do reator, expressa em termos de DQO bruta, foram de $49 \%$ e $68 \%$ na Etapa I e de $54 \%$ e $86 \%$ na Etapa II, para $\theta$ de 11 h e 8 h, respectivamente. Os resultados de DQO filtrada indicaram eficiências de remoção de $52 \%$ e $\mathrm{k}=$ $0,0857 \mathrm{~h}^{-1}$ para $\theta$ de $11 \mathrm{~h}$ e $42 \%$ e $\mathrm{k}=0,0880 \mathrm{~h}^{-1}$ para $\theta$ de $8 \mathrm{~h}$ na Etapa I. Na Etapa II, as eficiências de remoção foram 59\% e 51\% para $\theta$ de $11 \mathrm{~h}$ e $8 \mathrm{~h}$, com $\mathrm{k}=0,1238 \mathrm{~h}^{-1}$ e $\mathrm{k}=0,1075 \mathrm{~h}^{-1}$, respectivamente. O modelo cinético de primeira ordem indicou bom ajuste e descreveu adequadamente a cinética de remoção de matéria orgânica para $\theta$ de 11 h, com r ${ }^{2}$ igual a 0,9734 e 0,9591 para as Etapas I e II, respectivamente.

PALAVRAS-CHAVE: cinética, matadouro bovino, sistema combinado de tratamento.

\footnotetext{
${ }^{1}$ Tecnólogo Ambiental, Prof. Doutor, Departamento Acadêmico de Ambiental, UTFPR/Campo Mourão - PR, Fone: (44) 3518-1434, ckreutz@utfpr.edu.br.

${ }^{2}$ Eng $^{\mathrm{O}}$ Sanitarista, Prof. Doutor, Departamento Acadêmico de Química e Biologia, UTFPR, Curitiba - PR, fhpassig@utfpr.edu.br.

${ }^{3}$ Eng $^{\circ}$ Civil, Prof. Doutor, Departamento Acadêmico de Construção Civil, UTFPR, Curitiba - PR, kaquerne@utfpr.edu.br.

${ }^{4}$ Tecnólogo Ambiental, Prof. Doutor, Programa de Pós-Graduação em Tecnologias Ambientais, UTFPR/Medianeira - PR, juliana@utfpr.edu.br.

${ }^{5}$ Engo Agrônomo, Prof. Doutor, Programa de Pós-Graduação em Engenharia Agrícola, UNIOESTE/Cascavel - PR, simone.gomes@unioeste.br.
}

Recebido pelo Conselho Editorial em: 25-4-2013

Aprovado pelo Conselho Editorial em: 15-11-2013 


\section{INTRODUCTION}

In slaughterhouses, water consumption can be quite variable, since it is affected by the species and size of the animal being slaughtered, by cleaning practices adopted, layout, by the slaughter method and also by the degree of industrial automation. Typical consumption values may vary from 1 to $15 \mathrm{~m}^{3}$ of water per ton of slaughtered carcass (PACHECO \& YAMANAKA, 2006; LÓPEZLÓPEZ et al., 2010; MÉNDEZ-ROMERO et al., 2011).

The effluents from cattle slaughter are characterized by having high concentrations of organic matter that can range between 1100 and $10400 \mathrm{mg} . \mathrm{L}^{-1}$ in terms of COD, 600 to $6700 \mathrm{mg} . \mathrm{L}-1$ for BOD, from 90 to $3000 \mathrm{mg} . \mathrm{G}^{-1}$ for nitrogen, 300 and $6300 \mathrm{mg}^{-\mathrm{L}^{-1}}$ for suspended solids, as well as pathogenic and non-pathogenic agents, among other pollutants. Its main components are feces, food waste, undigested fat, blood, suspended matter, urine, small pieces of meat, soluble proteins and excrement, which must be subjected to appropriate treatment before being discharged into receiving bodies in order to reduce and/or eliminate adverse effects to the aquatic environment and public health (PACHECO \& YAMANAKA, 2006; DEBIK \& COSKUN, 2009; ÜN et al., 2009; . CAO \& MEHRVAR, 2011; DE NARDI et al., 2011).

CHAN et al. (2009 ) and RAJAKUMAR et al. (2012) state that highly polluting industrial effluents are treated preferentially by anaerobic systems, due to the high concentration of organic matter, lower production of excess sludge and the potential for power generation compared to conventional activated sludge processes. However, in practical applications, the anaerobic treatment becomes inefficient with a lower rate of microbial growth and lesser reduction of organic matter, hence the need for post-treatment.

Whereas the final effluent produced by the anaerobic treatment contains remaining organic matter, its combination with aerobic treatment becomes a suitable option to produce a quality final effluent to meet the standards required by the current environmental legislation. In this sense, new configurations of reactors have been studied with the aim of more efficient systems, with better utilization of the useful reactional volume, stability and easiness of operation. DOMINGUES (2005), CHERNICHARO (2006) and WANG et al. (2009) emphasize that the application of combined anaerobic-aerobic processes can provide significant improvements in the efficiency of wastewater treatment, as well as providing a number of advantages over conventional systems, among them, less power required for aeration in the aerobic phase, lower sludge production and lower costs of implementation and operation .

BODIK et al. (2003) state that the major difficulty of the application process in combined wastewater treatment is to find an optimal operating condition of the system, in order to achieve stability and efficiency of the system.

Therefore, the aim of this study is to evaluate the performance of an Anaerobic-Aerobic Fixed Bed Reactor (AAFBR) in the treatment of cattle slaughterhouse raw effluent, subjected to variations of hydraulic detention time $(\theta)$ and determine the kinetic constants of the organic matter degradation.

\section{MATERIAL AND METHODS}

The Anaerobic-Aerobic Fixed Bed Reactor (AAFBR) consisted of a tube of polymethyl methacrylate (acrylic), with an inner diameter of $90 \mathrm{~mm}$ and length of $1000 \mathrm{~mm}$, formed by a feed chamber and a reaction bed, with a total storage volume of $4.75 \mathrm{~L}$, where $2.85 \mathrm{~L}$ correspond to the anaerobic zone and $1.9 \mathrm{~L}$ to the aerobic.

For feeding and recirculation of the AAFBR, Provitec ${ }^{\circledR}$ peristaltic pumps, model DM5000, were used. Aeration was provided by a Boyu ${ }^{\circledR}$ air compressor; model S2000A, with air injection into the aeration chamber through porous rock in the aerobic area. The reactor was kept at room temperature throughout the operation. 
For immobilization of biomass of the AAFBR, two types of support material were used: expanded clay, with an average particle size ranging from $10 \mathrm{~mm}$ to $20 \mathrm{~mm}$ and cubic matrixes of polyurethane foam of $1 \mathrm{~cm}$ of edge, bulk density of $23 \mathrm{~kg} / \mathrm{m}^{3}$ and a porosity of approximately $95 \%$. The polyurethane foam of the anaerobic compartment of the AAFBR was inoculated by immersion, with approximately 15L of sludge from an anaerobic pond of the cattle slaughterhouse, over a period of ten days.

The substrate used to feed the AAFBR was composed of in natura raw agroindustrial effluent collected at the entrance of the cattle settling tank, whose physicochemical characteristics are presented in Table 1.

TABLE 1. Summary of the characteristics of the raw effluent used as substrate for the AAFBR.

\begin{tabular}{|c|c|c|c|}
\hline \multirow{2}{*}{ PARAMETERS } & \multicolumn{3}{|c|}{ AFFLUENT } \\
\hline & $\overline{\mathbf{x}}$ & MIN & MAX \\
\hline $\mathrm{pH}$ & $7.2 \pm 0.6$ & 6.2 & 8.5 \\
\hline Liquid temperatue $\left({ }^{\circ} \mathrm{C}\right)$ & $24 \pm 3$ & 15 & 28 \\
\hline $\mathrm{BA}\left(\mathrm{mg} \mathrm{CaCO} \mathrm{L}^{-1}\right)$ & $507 \pm 289$ & 119 & 1340 \\
\hline $\mathrm{AV}\left(\mathrm{mg} \mathrm{L}^{-1}\right)$ & $283 \pm 154$ & 44 & 782 \\
\hline Raw COD (mg L $\left.{ }^{-1}\right)$ & $1048 \pm 160$ & 837 & 1524 \\
\hline Filtered COD $\left(\mathrm{mg} \mathrm{L}^{-1}\right)$ & $888 \pm 209$ & 242 & 1432 \\
\hline TKN $\left(\mathrm{mg} \mathrm{L}^{-1}\right)$ & $321 \pm 136$ & 110 & 515 \\
\hline N-amon (mg L $\left.{ }^{-1}\right)$ & $191 \pm 49$ & 97 & 323 \\
\hline $\mathrm{N}-\mathrm{NO}_{2}{ }^{-}\left(\mathrm{mg} \mathrm{L}^{-1}\right)$ & $0.04 \pm 0.03$ & 0.01 & 0.11 \\
\hline $\mathrm{N}-\mathrm{NO}_{3}^{-}\left(\mathrm{mg} \mathrm{L}^{-1}\right)$ & $0.10 \pm 0.0$ & 0.10 & 0.10 \\
\hline Phosphorus (mg L ${ }^{-1}$ ) & $0.4 \pm 0.2$ & 0.0 & 0.6 \\
\hline $\mathrm{TS}\left(\mathrm{mg} \mathrm{L}^{-1}\right)$ & $2772 \pm 767$ & 1384 & 4273 \\
\hline $\mathrm{TSS}\left(\mathrm{mg} \mathrm{L}^{-1}\right)$ & $706 \pm 434$ & 166 & 2440 \\
\hline
\end{tabular}

Legend: $\bar{\chi}$ : arithmetic mean; MIN: minimum value; MAX: maximum value; BA: bicarbonate alkalinity; VA: volatile acids; COD:

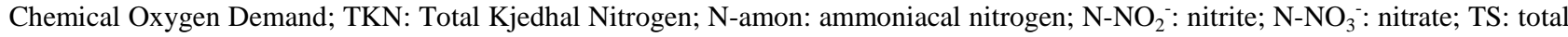
solids; TSS: Total suspended solids.

To evaluate the operational performance of the AAFBR, the reactor was subjected to a variation of $\theta$ in $11 \mathrm{~h}$ and $8 \mathrm{~h}$, with affluent average flow of $0.43 \mathrm{~L} \mathrm{~h}^{-1}$ and $0.60 \mathrm{~L} \mathrm{~h}^{-1}$ and organic load applied of $10.2 \mathrm{~g} \mathrm{~L}^{-1} \mathrm{~d}^{-1}$ and $13.3 \mathrm{~g} \mathrm{~L}^{-1} \mathrm{~d}^{-1}$, respectively.

Two operational steps were tested, with Step I corresponding to the combined operation (anaerobic-aerobic), with a continuous upward flow and without recirculation, and Step II, corresponding to the combined operation with recirculation of $50 \%$ of the affluent flow.

The behavior of the AAFBR was evaluated by monitoring the physical and chemical parameters: $\mathrm{pH}$, bicarbonate alkalinity (BA) $\left(\mathrm{mgCaCO}_{3} \cdot \mathrm{L}^{-1}\right)$, volatile acids (VA) $\left(\mathrm{mgHAc} \mathrm{L}^{-1}\right)$, chemical oxygen demand (COD) $\left(\mathrm{mg} \mathrm{L}^{-1}\right)$ of raw and filtered samples, total solids (TS) (mg L ${ }^{-1}$ ) and total suspended solids (TSS) (mg L ${ }^{-1}$ ) in samples of the affluent (substrate) and effluent, in accordance with the methods described in APHA (2005). Spatial sampling profiles were performed, that is, along the reactor height, for each $\theta \mathrm{h}$ evaluated, at the following sampling points: P0 (affluent reservoir of the AAFBR, equivalent to 0.0m); P1 (beginning of anaerobic area filled with expanded clay, $0.13 \mathrm{~m}$ high); P2 (the end of the anaerobic area filled with polyurethane foam, equivalent to $0.68 \mathrm{~m}$ high); P3 (beginning of the aerobic area filled with polyurethane foam, equivalent to $0.84 \mathrm{~m}$ high); and P4 (beginning of the compartment containing the treated effluent, equivalent to $0.93 \mathrm{~m}$ high).

The kinetic coefficients of organic matter degradation $(k)$, for the $\theta$ applied, were determined by fitting the data filtered of COD by first-order kinetic model, shown in eq.(1). The apparent kinetic parameters were obtained by fitting the decay curve of filtered COD, assuming a permanent basis of complete mixing and steady state. 
where,

$$
\ln \frac{|\mathrm{C}| \mathrm{t}}{|\mathrm{C}| \mathrm{u}}=-k \mathrm{t}
$$

$[\mathrm{C}]_{0}$ - concentration in the affluent $\left(\mathrm{mg} \mathrm{L}^{-1}\right)$;

$[\mathrm{C}]_{\mathrm{t}}$ - concentration in the effluent $\left(\mathrm{mg} \mathrm{L}^{-1}\right)$;

$k$ - reaction constan $\left(\mathrm{h}^{-1}\right)$, and

$\mathrm{t}$ - time (h)

\section{RESULTS AND DISCUSSION}

\section{AAFBR performance regarding the removal of organic matter}

The variations in $\mathrm{pH}$, bicarbonate alkalinity (BA) and volatile acids (VA) in the effluent samples over the height of AAFBR, referring to the operational steps I and II, with $\theta$ of $11 \mathrm{~h}$ and $8 \mathrm{~h}$ are shown in Figure 1.

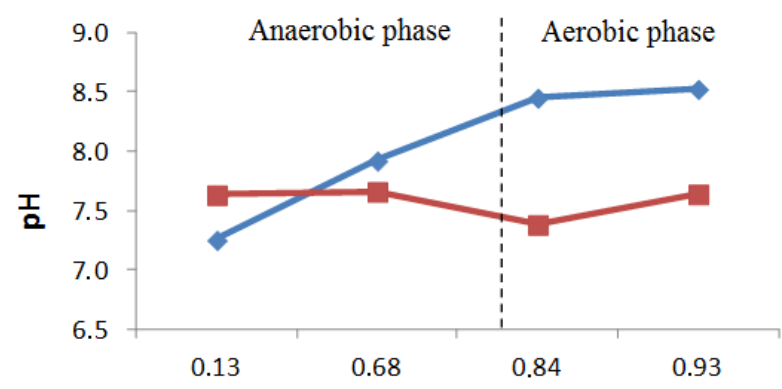

(a)

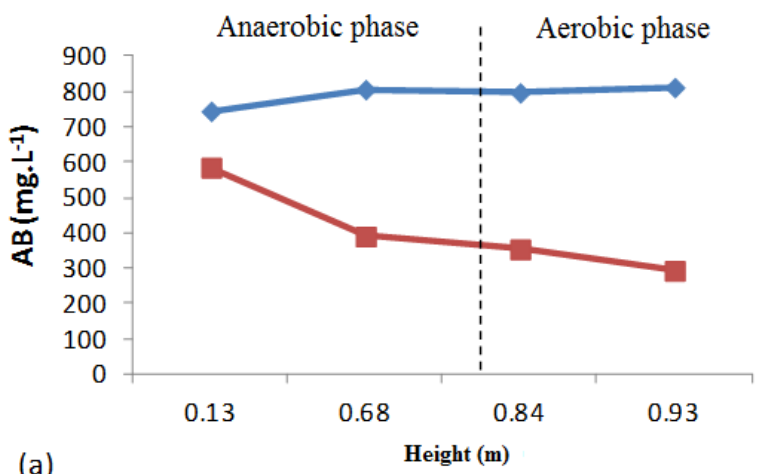

(a)

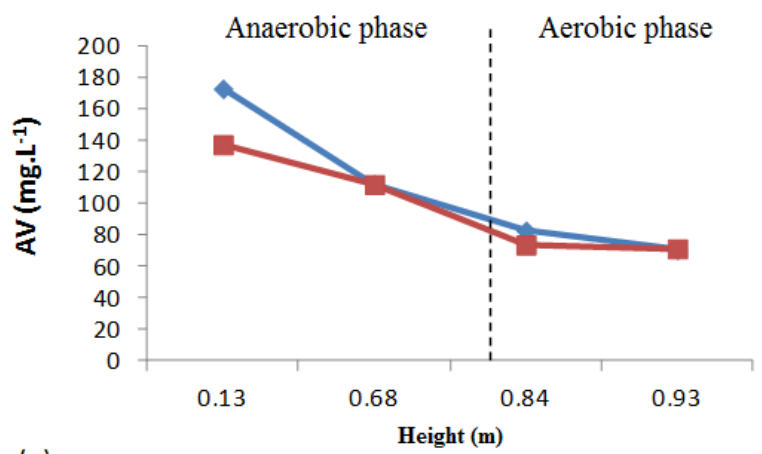

(a)

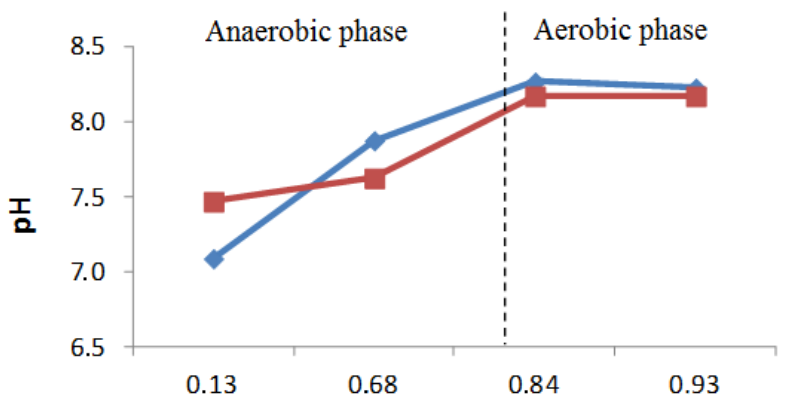

(b)
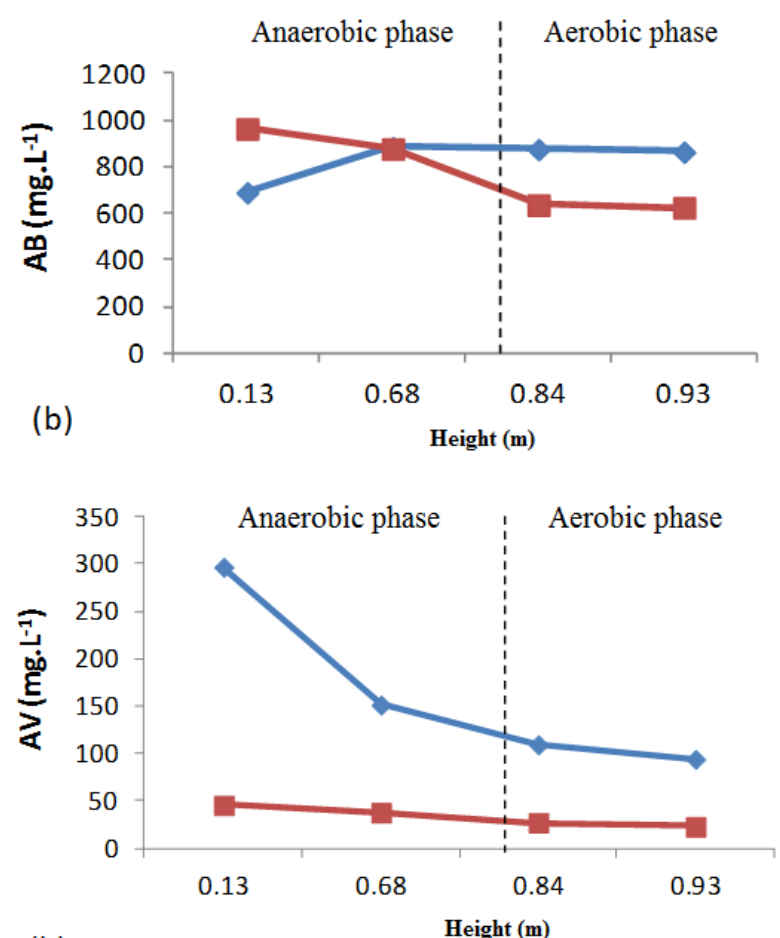

(b)

$\rightarrow$ Step I $\rightarrow$ Step II

FIGURE 1. Variations in the values of $\mathrm{pH}, \mathrm{BA}$ and VA along the height of the AAFBR for the operational Steps I and II for $\theta$ (a): $11 \mathrm{~h}$ and (b): $8 \mathrm{~h}$. 
Regarding the $\mathrm{pH}$, bicarbonate alkalinity and volatile acids, results indicate that AAFBR presented an ability to maintain favorable conditions for the biological processes involved in the removal of organic matter in both operating steps, since the alkalinity is sufficient to maintain the $\mathrm{pH}$ greater than 6.6 and the concentration of volatile acids below $250 \mathrm{mg} \mathrm{L}^{-1}$. Values of $\mathrm{pH}$ of the effluent observed in Step I were $8.0 \pm 0.6$ and $7.9 \pm 0.6 \theta$ for $11 \mathrm{~h}$ and $8 \mathrm{~h}$, respectively, and $7.6 \pm 0.1$ and $7.9 \pm \theta 0.4$ for $11 \mathrm{~h}$ and $8 \mathrm{~h}$, respectively in Step II.

The bicarbonate alkalinity ranged from $745 \pm 382$ to $812 \pm 66 \mathrm{mgCaCO}_{3} \mathrm{~L}^{-1}$ for $\theta$ of $11 \mathrm{~h}$ and $689 \pm 404$ and $863 \pm 497 \mathrm{mgCaCO}_{3} \mathrm{~L}^{-1}$ for $\theta$ 8h, during Step I along the height of the AAFBR. During Step II, with recirculation, a reduction of the bicarbonate alkalinity along the height of the AAFBR of $586 \pm 75$ to $294 \pm 220 \mathrm{mgCaCO}_{3} \mathrm{~L}^{-1}$ for $\theta$ of $11 \mathrm{~h}$ and $963 \pm 150$ to $625 \pm 263$ $\mathrm{mgCaCO}_{3} \mathrm{~L}^{-1}$ for $\theta$ of $8 \mathrm{~h}$. ABREU \& ZAIAT (2008) evaluated the performance of an anaerobicaerobic reactor filled with polyurethane foam for the treatment of sewage, operated with $\theta$ of $12 \mathrm{~h}$, and also confirmed the reduction of bicarbonate alkalinity of $143 \pm 38 \mathrm{mgCaCO}_{3} \mathrm{~L}^{-1}$ in the affluent and $58 \pm 62 \mathrm{mgCaCO}_{3} \mathrm{~L}^{-1}$ in the effluent when the reactor was operated in combined condition.

The concentration of VA during Step I ranged from $172 \pm 46$ to $71 \pm 5 \mathrm{mgHAc} \mathrm{L}^{-1}$ in $\theta 11 \mathrm{~h}$, and $297 \pm 94$ and $177 \pm 52 \mathrm{mgHAc} \mathrm{L}^{-1}$ in $\theta$ 8h. In Step II, these values were $137 \pm 85$ and $71 \pm$ $32 \mathrm{mgHAc}^{-1}$ for $\theta 11 \mathrm{~h} 46 \pm 6: 23 \pm 6 \mathrm{mgHAc}^{-1}$ for $\theta$ 8h. From Figure 1 , it is possible to see that the value of VA concentration in the effluent was lesser than the affluent over the height of the reactor to the operating conditions tested, characterizing balance of the organic matter removal process, and confirming the operational stability of the system.

NETTO (2011), when operating an anaerobic-aerobic reactor for sewage treatment in real scale, monitored the concentration of VA to evaluate the stability of the reactor and observed in his results similar behavior to the reported in this study, whose results showed a gradual reduction with average values of $56 \pm 14 \mathrm{mgHAc} \mathrm{L}^{-1}$ for the affluent and $17 \pm 2 \mathrm{mgHAc} \mathrm{L}^{-1}$ for the effluent with recirculation rate ( $r$ ) of zero; $25 \pm 7 \mathrm{mgHAc}^{-1}$ for $\mathrm{r}=1.5$ and $21 \pm 4 \mathrm{mgHAc} / \mathrm{L}$ for $\mathrm{r}=3.0$.

Therefore, the results showed stability of bicarbonate alkalinity during step I, after the step of anaerobic digestion and a gradual decrease in the concentration of volatile acids in the height of the reactor, as can be seen in Figure 1, indicating that there was oxidation of the organic matter in the anaerobic phase, with balance between acidogenic bacteria and methanogenic archaea, without accumulation of volatile acids inside the AAFBR. It is noteworthy that even with lower values of bicarbonate alkalinity in Step II, this variation did not indicate disturbance in the buffering system condition.

Figure 2 shows the variations in mean concentrations of TS, TSS and COD of raw and filtered samples along the height of AAFBR, referring to Steps I and II, $\theta 11 \mathrm{~h}$ and $8 \mathrm{~h}$, respectively, of effluent samples.

According to the results of the average concentration of the TS along the height of the AAFBR, it is possible to find that the system was efficient in terms of total solids removal during Step I, when the AAFBR was operated without recirculation, with removal efficiencies of $54 \%$ and $84 \%$ for $\theta 11 \mathrm{~h}$ and $8 \mathrm{~h}$, respectively, and in Step II efficiencies were 38 and $86 \%$.

It can be observed similarity in the behavior of the variation of the concentration of TS and TSS for both $\theta$ tested and the two operating steps, as shown in Figure 2. The removal efficiencies of TSS were $89 \%$ and $92 \%$ in Step I to $\theta 11 \mathrm{~h}$ and $8 \mathrm{~h}$, respectively, and 65 and 91\% in Step II. 


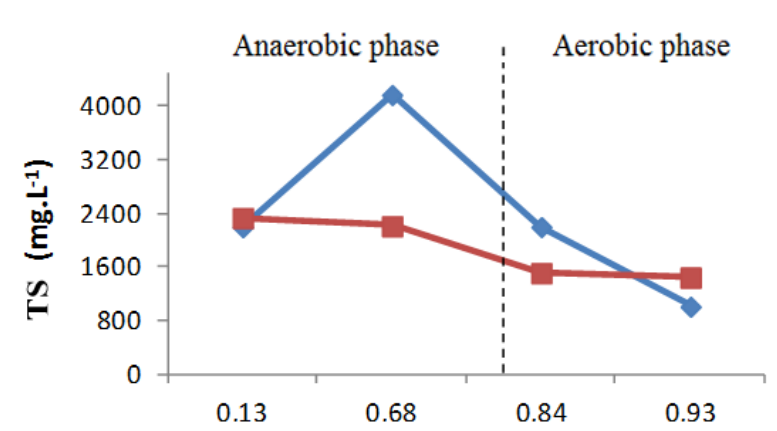

(a)

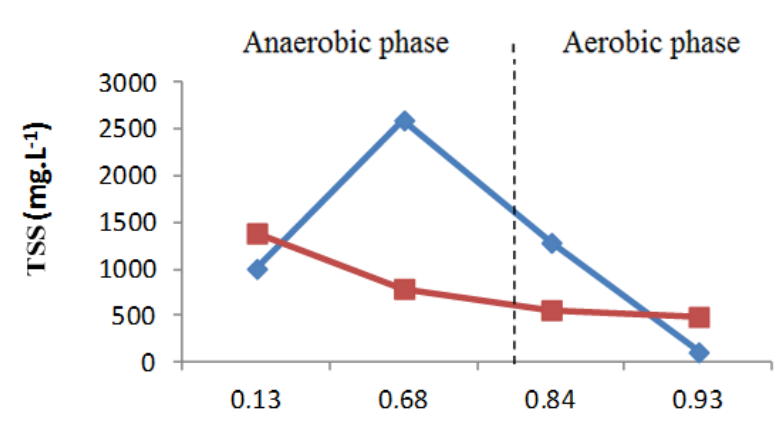

(a)

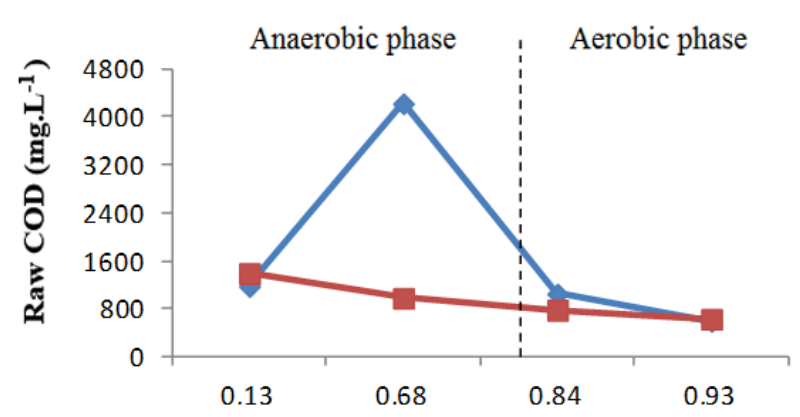

(a)

$$
\text { Height (m) }
$$

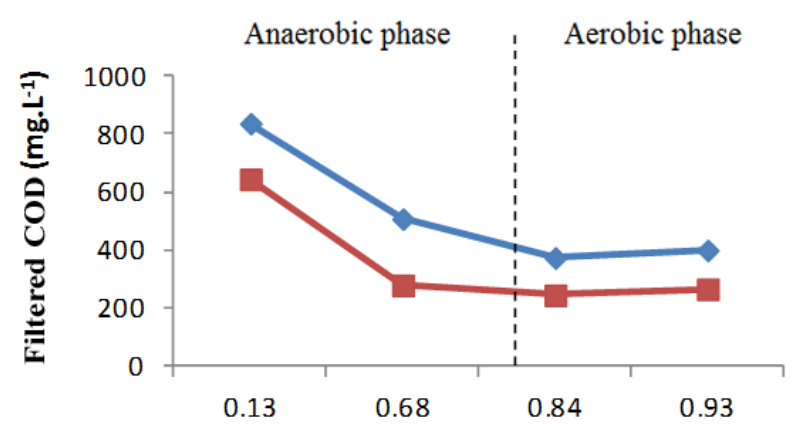

(a)

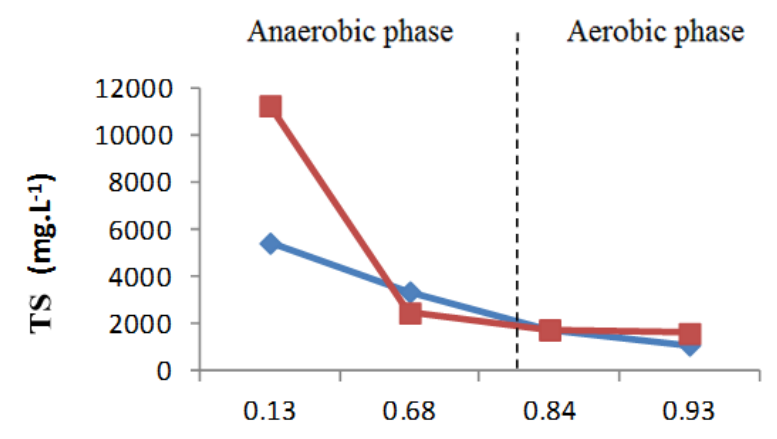

(b)

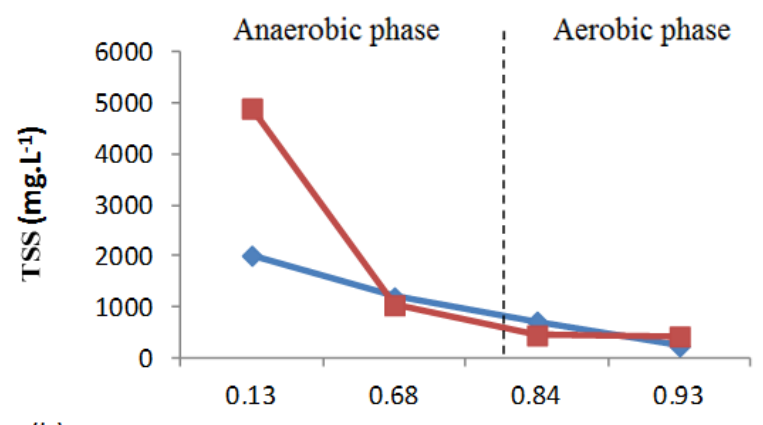

(b)
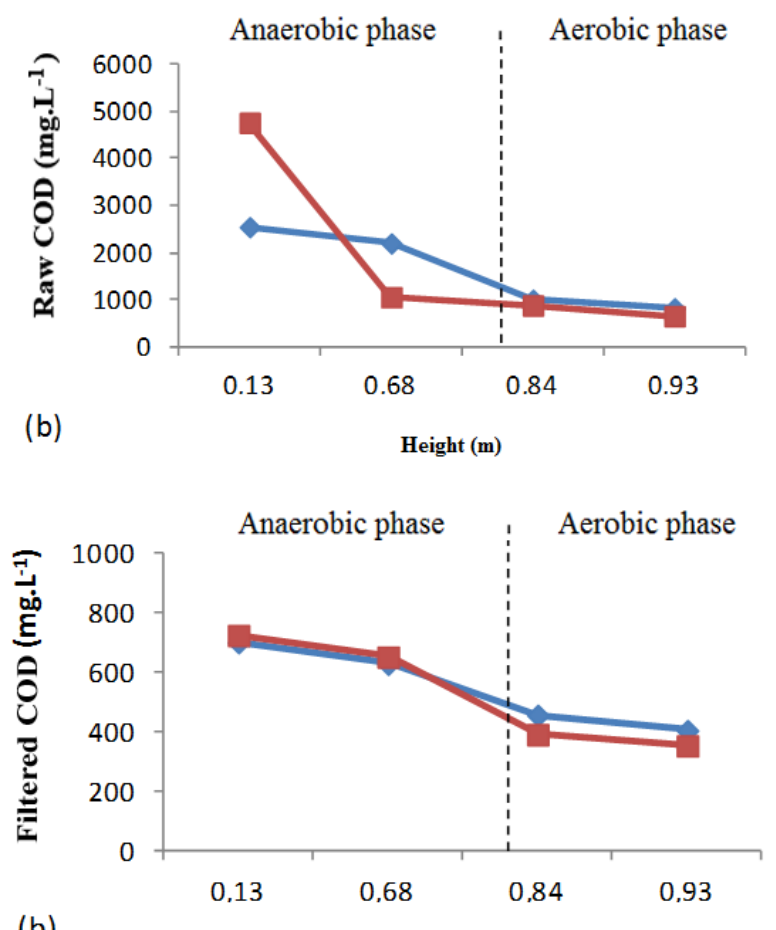

(b)

FIGURE 2. Variations in the values of TS, TSS and raw and filtered COD along the height of the AAFBR for the operational steps I and II for $\theta$ (a): $11 \mathrm{~h}$ and (b): $8 \mathrm{~h}$.

The analysis of the results suggests that Step I was advantageous in terms of removal of solids (total and suspended), compared to Step II, and the efficiencies achieved in this step may have been harmed by the increase in the upflow speed, promoted by recirculation of the effluent. A peak concentration of TS and TSS can be seen in Step I, for $\theta$ 11h, which can be attributed to excessive drag of solids, due to the detachment of biomass at the time of sample collection. 
The average removal efficiencies of organic matter along the height of the reactor, expressed in terms of raw COD were $49 \%$ and $68 \%$ in Step I and 54\% and 86\% in Step II, for $\theta 11 \mathrm{~h}$ and $8 \mathrm{~h}$, respectively. These results indicated apparent operational stability of the reactor, which can be justified by the increase liquid-solid mass transfer speed promoted by increased speed, due to the recirculation of the effluent.

The results of the COD filtered samples indicated removal efficiencies of $52 \%$ and $42 \%$ in Step I for $\theta 11 \mathrm{~h}$ and $8 \mathrm{~h}$, respectively, and 59\% and 51\% in Step II. There is a reduction in removal efficiency when decreasing $\theta$ from 11 h to 8 h, in both operating conditions. MARTíN et al. (2010) examined the kinetics of psychrophilic anaerobic digestion of synthetic sewage, using an upflow filter, formed by an acrylic column, with a useful volume of 1.35L, with immobilized biomass. Their results show that in $\theta$ of $10 \mathrm{~h}$ and $17 \mathrm{~h}$, removal efficiency of organic matter was almost constant and independent of $\theta$, with an average of $80 \%$. However, when the $\theta$ was lowered to $7 \mathrm{~h}$ and 3 h, the efficiency decreased to $77 \%$ and $65 \%$, with a corresponding increase in the proportion of volatile/alkalinity acids.

Comparing the values of COD in raw and filtered samples, the results indicate that most of the organic matter removal, approximately $10 \%$ and $60 \%$ of Step I, $43 \%$ and $81 \%$ in Step II for $\theta 11 \mathrm{~h}$ and $8 \mathrm{~h}$, respectively, occurred in the anaerobic compartment. The low yield occurred at $\theta$ of $11 \mathrm{~h}$ can be attributed to the interference of the acclimatization period, which may have been insufficient to allow increased removal of organic matter under anaerobic condition.

\section{Organic matter remotion kinects}

GHANIYARI-BENIS et al. (2010) point out that kinetic studies are useful to reproduce the empirical behavior of the degradation process of organic matter and understand the metabolic pathways of biodegradation and simultaneously save time and money. However, the development of a model of degradation of organic matter is complex and presents difficulties in view of the large number of variables, including the hydraulic detention time, substrate concentration and configuration of the reactors that affect and interfere with the anaerobic system and aerobic degradation.

The decay curves of organic matter, expressed in terms of filtered COD along the height of AAFBR, operated with $\theta$ of $11 \mathrm{~h}$, with and without recirculation, to a first order kinetic model, are presented in Figure 4.

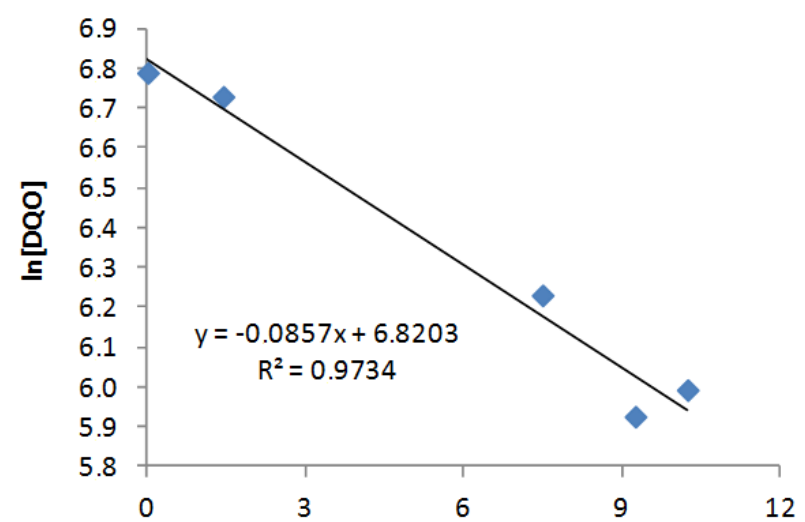

(a)

Time (h)

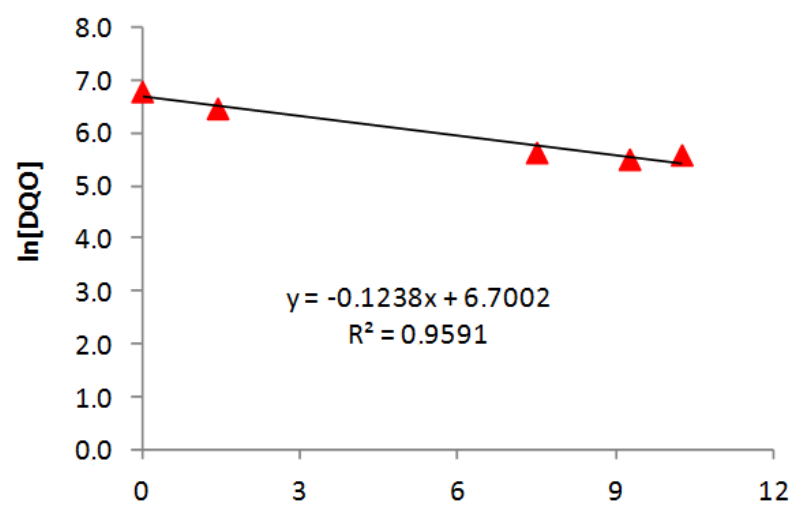

(b)

FIGURE 4. Decay curves of organic matter consumption along the height of the AAFBR for $\theta$ of 11h: (a) without recirculation; (b) with recirculation. 
The decay curves of organic matter, expressed in terms of filtered COD along the height of the AAFBR, operated with $\theta$ 8h, with or without effluent recirculation, to a first order kinetic model, are presented in Figure 5.
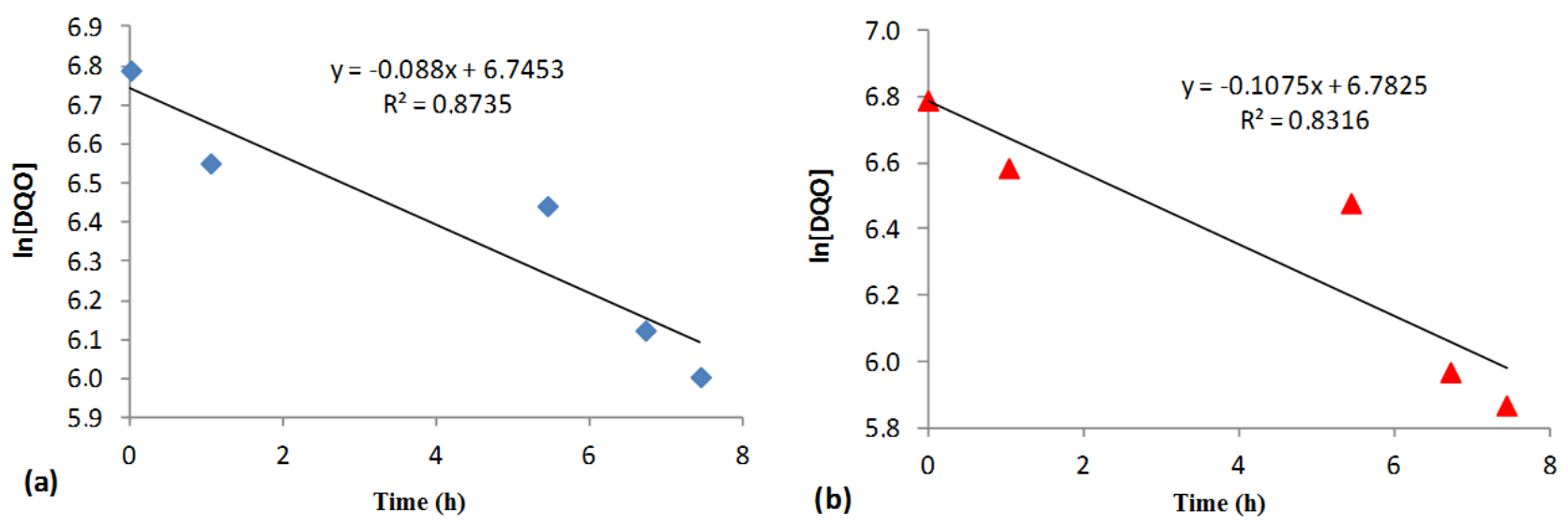

FIGURE 5. Decay curves of organic matter consumption along the height of the AAFBR for $\theta$ of 8h: (a) without recirculation; (b) with recirculation.

Table 2 shows the first order kinetics constant values which represent the consumption of organic matter, in terms of filtered COD and their respective correlation coefficients.

TABLE 2. Average parameters estimated from the first order kinetic model considering $\theta$ of $11 \mathrm{~h}$ and $8 h$.

\begin{tabular}{ccccc}
\hline \multirow{2}{*}{$\theta(\mathrm{h})$} & Operating condition & $\mathrm{k}\left(\mathrm{h}^{-1}\right)$ & $\mathrm{V}_{\mathrm{r}}\left(\mathrm{mg} \mathrm{L}^{-1} \mathrm{~h}^{-1}\right)$ & $\mathrm{r}^{2}$ \\
\cline { 2 - 5 } 11 & Step I & -0.0857 & -0.584 & 0.9734 \\
& Step II & -0.1238 & -0.829 & 0.9591 \\
\multirow{2}{*}{8} & Step I & -0.0880 & -0.682 & 0.8735 \\
& Step II & -0.1075 & -0.729 & 0.8316 \\
\hline
\end{tabular}

From the results shown in Table 2, it can be seen that when the AAFBR was operated with recirculation of the effluent in step II, in both $\theta$, the coefficients of organic matter removal $(\mathrm{k})$ are greater. This increase can be explained by the reduced mass transfer resistance caused by the recirculation of the effluent. This behavior can be seen in the larger removal efficiencies of filtered COD at this step.

FAZOLO (2003) evaluated kinetics parameters and mass transfer of a fixed bed radial reactor, at pilot scale, with immobilized biomass in polyurethane foam, fed with effluent from a HorizontalFlow Anaerobic Immobilized Biomass (HAIB) treating sanitary sewage and concluded that the resistance to mass transfer significantly affects the overall conversion speed in the system. The author has found values of first-order removal kinetics constants that ranged from $1.58 \mathrm{~h}^{-1}$ to $2.78 \mathrm{~h}^{-1}$. Both authors observed a tendency toward the apparent first-order kinetics constants with the increasing of air flow rate, due to the decrease of the external resistance to mass transfer as the air flow rate was increased.

CASTILLO et al. (1999) studied the kinetics of an anaerobic-aerobic combined system consisting of an UASB reactor followed by two RBC aerobic reactors (rotating biological contactor) in series, with air diffusers, treating domestic sewage. The authors found that the firstorder kinetic model was suitable to describe the degradation of organic matter in the combined system and obtained kinetic constants $(\mathrm{k})$ of $0.31 \mathrm{~h}^{-1}$ for a temperature of $19^{\circ} \mathrm{C}$ and $0.20 \mathrm{~h}^{-1}$ for a temperature of $12.5^{\circ} \mathrm{C}$ in the anaerobic unit. 
The results of the filtered COD samples of the present study indicate removal efficiencies of $52 \%$ for $\theta$ of $11 \mathrm{~h}$ and $\mathrm{k}$ of $0.0857 \mathrm{~h}^{-1}$, and $42 \%$ and of $\mathrm{k} 0.0880 \mathrm{~h}^{-1}$ for $\theta$ of $8 \mathrm{~h}$ for Step I. In Step II , the efficiencies were $59 \%$ and $51 \%$ for $\theta$ of $11 \mathrm{~h}$ and $8 \mathrm{~h}$, with values of $\mathrm{k}=0.1238 \mathrm{~h}^{-1}$ and $0.1075 \mathrm{~h}^{1}$, respectively. It is observed that the higher the apparent kinetics coefficient $(\mathrm{k})$ of the first order for degradation of organic matter, the higher the removal efficiency of COD, so there is a directly proportional to the performance of the AAFBR, as the greater the value of $(\mathrm{k})$, the higher the reaction rate and hence the more efficient the system.

PINHEIRO (2006) investigated the influence of varying the recirculation rate of the liquid phase and increase the substrate concentration on the stability, efficiency and kinetics of an anaerobic reactor, operated in sequential batch with recirculation of the liquid phase, and obtained removal efficiency of $79 \%$ for filtered samples with affluent COD of $1,000 \mathrm{mg} \mathrm{L}^{-1}$ and first-order kinetics constant of $1.14 \mathrm{~h}^{-1}$, whereas for COD of $1,500 \mathrm{mg} \mathrm{L}^{-1}$, the efficiency was $82 \%$ and the kinetics parameter was $1.31 \mathrm{~h}^{-1}$.

The obtained values of $\mathrm{r}^{2}$ (Table 2) confirmed that the first order kinetic model was more efficient to describe the behavior of AAFBR regarding the degradation of organic matter to the $\theta$ of $11 \mathrm{~h}$ with $\mathrm{r}^{2}=0.9734$ in Step I and $\mathrm{r}^{2}=0.9591$ in Step II, than for the $\theta$ of $8 \mathrm{~h}$, with $\mathrm{r}^{2}$ equal to 0.8735 and 0.8316 for Steps I and II, respectively.

ZAIAT \& FORESTI (1997) presented a methodology for estimating both apparent and intrinsic kinetics parameters of a horizontal-flow anaerobic immobilized biomass in polyurethane foam, operated with $\theta$ of $8 \mathrm{~h}$, treating glucose-based effluent. COD and volatile acids data were used to estimate the kinetics parameters. The authors stated that the first-order kinetic model showed the best fit to the experimental data and the apparent kinetics parameter resulted in $0.233 \mathrm{~h}^{-1}$ with a correlation coefficient of 0.998 .

GHANIYARI-BENIS et al. (2010) performed kinetics modeling of anaerobic degradation of a chambered hybrid anaerobic reactor, operated at mesophilic temperature in treating synthetic sewage. The results obtained for the kinetics constant $(\mathrm{k})$ was $0.60 \mathrm{~h}^{-1}$ assuming a hydrodynamic behavior of reactors in series and steady state conditions. The authors concluded that the first-order kinetic model was adequate to reproduce the degradation of organic matter with $r^{2}=0.9995$ when operated with $\theta$ of $8 \mathrm{~h}$ and $\mathrm{r}^{2}=0.9996$ for $\theta$ of $16 \mathrm{~h}$.

LUIZ (2007) conducted an operational evaluation of three upflow anaerobic fixed bed reactors containing immobilized biomass of blast-furnace slag, polyurethane foam and gravel, in the treatment of wastewater from processing coffee fruit. The author reports that the reactor filled with polyurethane foam showed better removal efficiency of organic matter in terms of filtered COD samples (83\%), compared to the other media materials, and confirmed that the first-order kinetic model for this operating condition was able to describe the behavior of upflow anaerobic reactors, with values of $\mathrm{k}$ equal to $0.0854 \mathrm{~h}^{-1} ; 0.0795 \mathrm{~h}^{-1}$ and $0.1666 \mathrm{~h}^{-1}$.

\section{CONCLUSIONS}

Considering the results of raw COD samples, it can be concluded that the reduction of $\theta 11 \mathrm{~h}$ to 8h promoted an increase in the removal efficiency of organic matter in both operational steps.

Regarding $\mathrm{pH}$, bicarbonate alkalinity and volatile acids, the results indicate that AAFBR showed an ability to maintain favorable conditions for the biological processes involved in the removal of organic matter in both operational steps. The bicarbonate alkalinity and gradual decrease in the concentration of volatile acids along the height of the reactor showed a buffering system, balance between the acidogenic bacteria and methanogenic archaea in the anaerobic phase and the consumption and generation of alkalinity in the processes of nitrification and denitrification of the aerobic phase. 
The first-order kinetic model indicated good fit and adequately described the kinetics of removal of organic matter of AAFBR for $\theta$ of $11 \mathrm{~h}$, with $\mathrm{r}^{2}$ equal to 0.9734 and 0.9591 for Steps I and II, respectively. In conclusion, from the values of the kinetics coefficients of the first order for degradation of organic matter, the higher the values of $k$ ) found, the higher the removal efficiency of COD.

\section{ACKNOWLEDGEMENTS}

The authors would like to thank CNPq (process 482321/2009-1) and Fundação Araucária (process 23.078/2012), Secretary of State for Science, Technology and Higher Education of Paraná (SETI-PR) and to the Government of the State of Paraná for the financial support.

\section{REFERENCES}

ABREU, S.B.; ZAIAT, M. Desempenho de reator anaeróbio-aeróbio de leito fixo no tratamento de esgoto sanitário. Engenharia Sanitária e Ambiental, Rio de Janeiro, p. 181-188, abr. 2008.

APHA. Standard methods for the examination of water and wastewater. $21^{\text {th }}$ ed. Washington: American Public Health Association; American Water Works Association; Water Pollution Control Federation. 2005.

BODÍK, I.; KRATOCHVÍL, K.; GASPARIKOVÁ, E.; HUTÑAN, M. Nitrogen removal in an anaerobic baffled filter reactor with aerobic post-treatment. Bioresource Technology, [s.l.], p.79-84, 2003.

CAO, W.; MEHRVAR, M. Slaughterhouse wastewater treatment by combined anaerobic baffled reactor and $\mathrm{UV} / \mathrm{H}_{2} \mathrm{O}_{2}$ processes. Chemical Engineering Research \& Design, v.89, p.1136-1143, 2011.

CASTILLO, A.; LLABRES, P.; MATA-ALVAREZ, J. A kinetic study of a combined anaerobicaerobic system for treatment of domestic sewage. Water Research, v.33, n.7, p.1742-1747, 1999.

CHAN, Y.J.; CHONG, M.F.; LAW, C.L.; HASSELL, D.G. A review on anaerobic-aerobic treatment of industrial and municipal wastewater. Chemical Engineering Journal, [s.l.], p. 1-18, 2009.

CHERNICHARO, C.A. de L. Post-treatment options for the anaerobic treatment of domestic wastewater. Environmental Science and Biotechnology, [s.l.], p.73-92, 2006.

DE NARDI, I.R.; DEL NERY V.; AMORIM, A.K.B.; SANTOS, N.G.; CHIMENES, F. Performances of SBR, chemical-DAF and UV disinfection for poultry slaughterhouse wastewater reclamation. Desalination, Amsterdam, v.269, p.184-189, 2011.

DEBIK E.; COSKUN T. Use of the Static Granular Bed Reactor (SGBR) with anaerobic sludge to treat poultry slaughterhouse wastewater and kinetic modeling. Bioresource Technology, Essex, v.10, p.2777-2782, 2009.

DOMINGUES, L. M. Sistema combinado filtro anaeróbio - biofiltro aerado submerso: avaliação da partida e da nitrificação de esgoto sanitário. Campinas: Lígia Maria Domingues, [s.n.], 2005.

FAZOLO, A. Determinação de parâmetros cinéticos e de transferência de massa em reator radial aeróbio-anóxico alimentado com esgoto sanitário tratado em reator anaeróbio. 2003. 198 f. Tese (Doutorado) - Escola de Engenharia de São Carlos, Universidade de São Paulo, 2003, São Carlos, 2003.

GHANIYARI-BENIS, S.; MARTÍN, A.; BORJA, R. Kinetic modeling and performance prediction of a hybrid anaerobic baffled reactor treating synthetic wastewater at mesophilic temperature.

Process Biochemistry, London, v.45, p.1616-1623, 2010. 
LÓPEZ-LÓPEZ, A.; VALLEJO-RODRÍGUEZ, R.; MÉNDEZ-ROMERO, D.C. Evaluation of a combined anaerobic and aerobic system for the treatment of slaughterhouse wastewater.

Environmental Technology, London, v.31, n.3, p.319-326, 2010.

LUIZ, F.A.R. Desempenho de reatores anaeróbios de leito fixo no tratamento de águas residuárias da lavagem e descascamento/despolpa dos frutos do cafeeiro. 2007. 132 f. Dissertação (Mestrado) Universidade Federal de Viçosa, Viçosa, 2007.

MARTÍN, M.A.; RUBIA, M.A. de la; MARTÍN, A.; BORJA, R.; MONTALVO, S.; SÁNCHEZ, E. Kinetic evaluation of the psychrophilic anaerobic digestion of synthetic domestic sewage using an upflow filter. Bioresource Technology, Essex, v.101, p.131-137, 2010.

PACHECO, J. W. F.; YAMANAKA, H. T. Guia técnico ambiental de abates (bovino e suíno). São Paulo: CETESB, 2006. 98 p. (Série P + L).

PINHEIRO, D.M. Influência da velocidade de recirculação no tratamento anaeróbio de esgoto sintético em biorreator operado em batelada sequencial contendo biomassa granulada. 2006. 156 f. Dissertação (Mestrado em Engenharia de Processos Químicos e Bioquímicos) - Escola de Engenharia Mauá, Centro Universitário do Instituto Mauá de Tecnologia, São Caetano do Sul, 2006.

MÉNDEZ-ROMERO, D.C.; LÓPEZ-LÓPEZ, A.; VALLEJO-RODRÍGUEZ, R.; LEÓNBECERRIL, E. Hydrodynamic and kinetic assessment of an anaerobic fixed-bed reactor for slaughterhouse wastewater treatment. Chemical Engineering and Processing, v.50, p.273-280, 2011.

NETTO, A.P. de O. Reator anaeróbio-aeróbio de leito fixo em escala piloto, com recirculação da fase líquida, aplicado ao tratamento de esgoto sanitário. 2011. 169 f. Tese (Doutorado) - Curso de Engenharia Civil, Escola de Engenharia de São Carlos, Universidade de São Paulo, São Carlos, 2011.

RAJAKUMAR, R.; MEENAMBAL, T.; SARAVANAN, P.M.; ANANTHANARAYANAN, P. Treatment of poultry slaughterhouse wastewater in hybrid upflow anaerobic sludge blanket reactor packed with pleated poly vinyl chloride rings. Bioresource Technology, Sausanne, v.103, p.116122, 2012.

ÜN, Ü. T.; KOPARAL, A. S.; ÖGÜTVEREN, Ü. B. Hybrid processes for the treatment of cattleslaughterhouse wastewater using aluminum and iron electrodes. Journal of Hazardous Materials, Amsterdam, v.164, p.580-586, 2009.

WANG, L.; SHAMMAS, N. K.; HUNG, Y.-T. Advanced biological treatment processes. New York: Humana Press, 2009. 739 p.

ZAIAT, M.; FORESTI, E. Method for estimating the kinetics of substrate degradation in horizontalflow anaerobic immobilized sludge reactors. Biotechnology Techniques, Kew, v.11, n.5, p.315-318, 1997. 